\title{
History Teacher Candidates' Evaluation of Their Undergraduate Programs
}

\author{
Osman Akhan ${ }^{1, *}$ \\ ${ }^{1}$ Social Studies Education, Faculty of Education, Akdeniz University, Antalya 07058, Turkey \\ *Correspondence: Social Studies Education, Faculty of Education, Akdeniz University, Antalya 07058, Turkey. Tel: \\ 90-242-227-4401/4629. E-mail: osmanakhan07@gmail.com
}

Received: March 19, 2021

Accepted: April 13, $2021 \quad$ Online Published: May 12, 2021

doi:10.5430/jct.v10n2p1

URL: https://doi.org/10.5430/jct.v10n2p1

\begin{abstract}
The aim of this research is to reveal the thoughts on the history program of the teacher candidates who have recently graduated from the history teaching undergraduate program. In this research, a case study model from qualitative research methods was adopted. The study group of this research consisted of 49 teacher candidates, 18 female and 31 male. The teacher candidates were senior students to graduate at the end of the 2019-2020 academic year, and they were selected from education faculties at three state universities. Within the framework of this study, an easily attainable method was adopted in the selection of universities and faculties, and the criterion sampling, a purposeful sampling method, was used while choosing the study group. The data of the study were collected via e-mail correspondence with a questionnaire consisting of open-ended questions created by the researcher. The data obtained from the study group were analyzed using descriptive analysis. When the results of the study are evaluated in general, it could be stated that the history teacher candidates in the study group mostly have positive opinions about their undergraduate education. However, teacher candidates expressed that the course contents were very theoretical and added that the number of practical courses should be increased.
\end{abstract}

Keywords: history education, history undergraduate program, teacher candidate, thoughts about the program

\section{Introduction}

History functions as a laboratory, since it provides information about the behavior of people and societies and vital evidence from the past. (Stearns, 2009), because it helps understanding and embracing the historical heritage and gaining a national identity (White, 1992; Watts, 1993). History offers the opportunity to control the future, as it shapes expectations for the future with information from the past (Torp, 2014; Crabtree, 2001; Taylor \& Young, 2003). In addition, it has important roles such as developing awareness of citizenship, gaining sense of social belonging, and supporting identity development (Lorentzen, 2000; Fausser, 2000; Nair \& Narayanasamy, 2017). On the other hand, this identity development contributes to being a good citizen by improving moral understanding (Stearns, 2009).

In order to access the laboratory of human experiences, it is necessary to learn history (Stearns, 2009), since history handles the essence of events and it provides the transfer of important retrospective moments (Crabtree, 2001). Yet, history is regarded as a "difficult" course in terms of the subjects it covers (Steeves, 1998), as historians do not arrest criminals, repair highways, or perform heart transplants. For this reason, since the products presented in historical studies are not concrete and tangible, determining their functions is more difficult and often notional than in fields such as medicine or engineering (Stearns, 2009). However, according to Bal (2011), this state of being abstract creates a positive effect in comprehending and visualizing the information from the past. The reason for this is that courses usually accepted by people are preferred since they attract attention of the people and include their ways of thinking. For this reason, while many people tend to move away from these courses, a certain part of them questions why history should be learned and what is the purpose of it (Stearns, 2009). At this point, teachers should have the competence to turn this into a positive effect. Regarding this, İlhan (2005) states that there are basically three field concepts that a teacher should have. These are teaching knowledge, field knowledge and general culture knowledge 
competencies. In the teaching field qualifications established by the Ministry of National Education (2018), it has been determined that there is no special area competency for each branch. Moreover, it is observed that the special area competencies previously in effect for the branches were abolished as of 2018.

When the general competencies of the teaching profession recently updated by the Ministry of National Education are examined, it is seen that there are three areas of competence that complement each other as professional skills, professional knowledge and attitude-values by virtue of the age of change we live in. These competency areas have eleven sub-competencies and sixty-five indicators. The sub-competencies in the field of professional knowledge are field knowledge, field education knowledge, and legislation information. Among the sub-competencies of professional skill competencies are education planning, creating learning environments, managing the teaching and learning process, measurement and evaluation processes. There are national, moral and universal values, approach to the student, communication and cooperation, personal and professional development in the sub-competencies of attitudes and values competence. When the usage areas of all these competencies are analyzed, there are pre-service teacher training, teaching practice, teacher candidate training process, teacher employment, self-evaluation, performance evaluation, career development and rewarding, continuous professional development and academic courses (Ministry of Education, 2017; Tosuntaş, 2020).

Considering how history teachers are trained in the light of these general competencies of teaching profession, it is seen that the history teaching undergraduate program goes through a process that covers eight terms, that is, four years of education. In this program, history teacher candidates receive an education consisting of a total of 151 credits and 168 course hours (Council of Higher Education (CoEH), 2018; Turan, 2019). In the program, it is observed that there are courses given under three categories: professional knowledge, general culture and field education. When the course weights of these categories are investigated, it is acknowledged that the teacher candidates receive a training covering 74 hours for field education. And also, the other courses they take consist of 56 hours of professional knowledge and 28 hours of general culture. Additionally, it is ensured that students gain practical experience in the field by taking Teaching Practice I-II courses in the first and second terms of the fourth year. (CoEH, 2018).

A well-trained, well-educated history teacher would undoubtedly contribute to the training of well-educated students, given the fact that a well-trained history teacher also has the ability to transfer knowledge more easily and effectively by knowing how to attract her/his student to class as a teacher who has discovered ways to endear his/her lesson. Since all this would also help a teacher grow up with the desired citizenship competencies, which is one of the primary goals of the teacher, the education a teacher receives before the service is therefore very essential (Karabağ, 2010; Culpin, 2007; Nair \& Narayanasamy, 2017). The history teacher themselves should also be open to continuous development in order to train students to get to a point where they can evaluate evidences, conflicted comments, and patterns happened in the past. As history teachers can support the creative thinking of their students as long as teachers are open to research, questioning and learning new things. In this way, the students they train would be able to think critically, have strong empathy skills, have a skeptical approach to information they learn, and be willing to do research (Angvik, 2001; Lee's 1984; Ogunniyi, 2012).

While providing history teaching, the sharp distinction between content and pedagogical process should be eliminated, and content, pedagogy training and curriculum should be well organized (Shulman,1986). For this reason, the purpose of the methods and techniques to be used in history teaching should be oriented to have students obtain abstract concepts, comprehend the events happened in the past, and envision the events carried to the present in the students' mind. (Honey, 2011). Students often have difficulty remembering events that do not have an ongoing impact on the present day, as they are more prepared to receive information selectively (Wineburg, 2000). Hence, they may regard history as a boring lesson from time to time (Crabtree, 2001; Nair \& Narayanasamy, 2017; Demircioğlu, 2008; Fielding, 2005). However, it is possible to make this "boring" lesson dynamic and fun with various methods that can be applied. At this point, history lesson should especially be saved from the spiral of textbooks, classrooms and teachers. (Avc1 Akçal1, 2015). Works and stories about military history and biographies that can be used by the history teacher in accordance with the subject, are among the methods that can contribute to this (Stearns, 2009). For example, making use of films and visual materials in the teaching of the subjects in the Turkish Education History course would help to increase the effectiveness and liveliness of the course (Alabaş, 2016). In addition to historical films, historical timelines, Internet, timelines, and supplementary resources can also be used (McDiarmid \& Vinten Johnson, 2000; Boadu, 2015; Nygren, 2011). On the other hand, for an effective learning in history education, the course should be supported by various methods such as providing teaching practices outside the classroom, utilizing oral and visual documents (Schanely, 2006; Kyvig \& Marty, 2000), utilizing museums and historical places, and implementing local history activities. And the teacher should also be 
trained with these knowledge, experience and competencies before the service (Ata, 2001; Demircioğlu, 2008; Epic, 2004; Aktekin, 2009).

Many teachers are dealing with the challenges they face on a daily basis in the service. Also before the service, many teacher training programs do not adapt to these difficulties and provide teacher candidates with sufficient experience (Stanovich \& Jordan, 2002). However, it is essential for teacher candidates to have experiences, pedagogical competence, field knowledge as well as educators that they could take on a role for in-service training (Conderman \& Walker, 2015). Most of the difficulties experienced by recently graduated teachers arise from issues related to classroom management and feeling of unreadiness. And when the teacher candidates are asked about this situation, they mention that they have little experience (Kent, 2000). Hence in this direction, determining the opinions of teacher candidates about their own undergraduate program is considered to be important in terms of completing their professional development before the service within the scope of our research. In the literature, although there are studies in different fields, it is thought that this study will contribute to the teaching history in terms of the fact that there has not been a study that reveals the opinions of history teacher candidates towards the history undergraduate program. In this direction, the aim of the research is to reveal the thoughts of teacher candidates who have recently graduated from the history teaching undergraduate program on the history program.

\section{Method}

This research was patterned with the case study, one of the qualitative research methods, in order to reveal the thoughts about the history program of the teacher candidates who have recently graduated from the history teaching undergraduate program. Case study is an in-depth examination and description of a limited system (Merriam, 2018). Case studies are used to describe, identify, and discover events that are supposed to have causal connections between them (Yin, 1984). The case to be chosen as a research subject could be a person, a student, an administrator, a program or groups such as class, school, community. Along with these, the case may also be a process that includes application steps such as undergraduate curriculum (Creswell, 2007). In this research, history undergraduate programs were chosen as research subject.

\subsection{Study Group}

The study group of this research consisted of 49 teacher candidates, 18 female and 31 male. The teacher candidates were senior students to graduate at the end of the 2019-2020 academic year, and they were selected from education faculties at three state universities. In the study, an easily attainable method was used in the selection of the university and faculty, and the criterion sampling of the purposeful sampling method was used while choosing the study group. Criterion sampling "aims to work with individuals who meet pre-determined conditions" (Yıldırım \& Şimşek, 2013). The convenience sample in the study was opted for, because it was easy to access, and it provided "speed and practicality" to the research (Büyüköztürk, Kılıç Çakmak, Akgün, Karadeniz \& Demirel, 2008). In this study, the selection criteria of the study group were determined as "to be a history teacher candidate as a senior year student, and to be at the graduation stage by completing the internship at the end of the 2019-2020 academic year". While determining the study group, the participation of students in the study was completely adhered to the principle of volunteering.

\subsection{Collection and Analysis of Data}

In the process of collecting the data of this research, online education started due to the pandemic process in spring 2020. When this process started, the history teacher candidates in the study group completed the term through online education after 5 weeks of face-to-face training, and then they graduated. Due to course of the process, the data from the teacher candidates at the graduation stage were collected by correspondence via e-mail, since there was no face-to-face meeting opportunity due to the pandemic. "In addition to the fact that e-mail correspondences can be online, they can also be carried out in-depth and including multiple e-mail exchanges without the need for simultaneous presence" (Creswell, 2018; Meho, 2006; Kazmer \& Xie, 2008). The written information obtained from the teacher candidates were organized simultaneously by two different field expert researchers besides the researcher, and accepted as a data set.

Descriptive analysis was used in the analysis of the collected data. After the findings obtained in the descriptive analysis are edited, they are interpreted and presented to the reader. The purpose here is to first describe the data systematically and clearly, then to explain and interpret these descriptions, and to reach some results within the cause and effect connection (Yıldırım \& Şimşek, 2013). In order to the eliminate reliability of the analyses of the research and the bias of the researcher, the coding was made with the help of two field expert researchers besides the 
researcher, and the analysis continued until all researchers agreed. The coder reliability was calculated through "P $($ Consensus Percentage\%) $=[\mathrm{Na}($ Consensus $(81)) / \mathrm{Na}$ (Consensus (81)) $+\mathrm{Nd}$ (Disagreement (8)) $]$ X 100 formula suggested by Miles and Huberman (1994), and 91 percent value was reached. In addition, the findings were supported by direct quotations from answers teacher candidates (with the abbreviations such as $1 \mathrm{HTC}: 1^{\text {st }}$ History teacher candidate; $2 \mathrm{HTC}: 2^{\text {nd }}$ History teacher candidate...).

\section{Findings}

This part of the study includes the findings obtained from the opinions of history teacher candidates who make up the study group regarding their undergraduate education.

\subsection{Findings Regarding the Evaluation of the Undergraduate Education They Received}

The history teacher candidates in the study group were asked to evaluate their undergraduate education they received in general. The answers given by teacher candidates are shown in Table 1.

Table 1. Evaluation of Undergraduate Education

\begin{tabular}{llc}
\hline & Codes & $\mathrm{f}$ \\
\hline \multirow{3}{*}{ Positive } & Qualified education & 25 \\
& Sophisticated faculty members & 18 \\
& Field training is adequate & 13 \\
& Renowned faculty members & 6 \\
I liked my field & 4 \\
& Inadequate educational sciences & 17 \\
& Too much detailed information & 8 \\
& Few practical courses & 4 \\
\hline
\end{tabular}

According to Table 1, it can be suggested that teacher candidates generally make positive evaluations about their undergraduate education. Teacher candidates evaluated the education they received as a qualified one, and as for the negative features, they stated that there are few educational sciences courses while too many courses with theoretical content. Here are the answers from some of the teacher candidates:

2HTC: I think the field courses are adequate, however I was poor at educational sciences courses, educational courses were always conducted in an incomplete and unsuccessful manner.

8HTC: In my undergraduate education, the field courses were very good and adequate, but I realized at the time of the internship that the educational sciences courses fell short. By reducing the detailed information in the field courses, applications suitable for our field can be adopted in educational sciences.

22HTC: The education I received is quite qualified. It would surely be nice to see more practical examples in educational sciences, but I think I can meet these gaps with my own efforts.

26HTC: The education I received is definitely not merely enough to become a teacher when I graduate. Although we received very useful information about the field from our well-equipped instructors, we should have had more practical courses to teach.

\subsection{Findings Regarding the Evaluation of Their Dream History Teacher}

The history teacher candidates in the study group were asked to describe their dream history teacher. The responses given by teacher candidates are shown in Table $2 \mathrm{a}$.

According to Table 2a, teacher candidates expressed their dream history teacher as a good historian who abandoned traditional patterns in history teaching, a teacher who can keep the interest of students alive, and has a command of educational sciences as well as field knowledge. When the answers of teacher candidates are analyzed, it can be claimed that they depict a teacher who is conforming with innovative history teaching, who endears history, who tells the history enthusiastically, and who is open to innovations. In addition to this question, teacher candidates were asked to evaluate the contribution of the education they received to their dream history teacher. The answers of teacher candidates are shown in Table $2 b$. 
Table 2a. Evaluations of History Teacher Candidates on Their Dream History Teacher

\begin{tabular}{lc}
\hline Codes & $\mathrm{f}$ \\
\hline Abandoned traditional patterns & 23 \\
Can keep students interest alive & 16 \\
Combines field knowledge with educational sciences & 11 \\
Open to innovations & 6 \\
Makes people feel history & 4 \\
Endears history & 4 \\
Loves her/his profession & 3 \\
Delivers the lecture enthusiastically & 2 \\
Good historian & 2 \\
Aware of current events & 2 \\
Has a good command of technology & 2 \\
Enthusiastically committed to her/his work & 1 \\
Versatile & 1 \\
\hline
\end{tabular}

Table 2b. Evaluation of the Contribution of the Education they Received to Their Dream History Teacher

\begin{tabular}{ll}
\hline Codes & $\mathrm{f}$ \\
\hline Not adequate but it guided me. & 16 \\
Not adequate & 13 \\
Adequate & 12 \\
Absolutely adequate & 8 \\
\hline
\end{tabular}

When Table $2 \mathrm{~b}$ is analyzed, it can be stated that teacher candidates generally consider their undergraduate education adequate enough to meet their expectations from a dream history teacher. Candidates who did not find it adequate stated that they found undergraduate education still useful in terms of guidance. Some of the answers given by teacher candidates to both questions are as follows:

6HTC: A well-equipped teacher who has stripped herself/himself of what is often known as boring stereotype and can keep interest of her/his students alive. The education I received is adequate in terms of knowledge, yet I also need to improve myself.

18HTC: A history teacher who loves history, a history teacher who erases the perception of a worthless, unnecessary lesson from minds, that is my history teacher dream I cannot say that the education I received completely contributes to this.

21HTC: My dream history teacher should describe any event $\mathrm{s} /$ he tells with excitement as if s/he had experienced it, and $\mathrm{s} /$ he should be able to convey this feeling to the student. Of course, my education contributes to my efforts to become such a teacher. I also try to consolidate it by reading books in my own field.

21HTC: I am against the history teachers telling their lessons as stories. A history teacher should love and endear her/his profession S/he should include more visual and audial materials in her/his lecture, arouse curiosity among students, and also be able to use technology effectively in her/his lessons. Along with these, of course, s/he should have good command of field knowledge and be aware of current events. I believe that the education I received will meet these expectations.

3.3 Findings Regarding the Best and Worst Experiences of History Teacher Candidates during Their Undergraduate Education

History teacher candidates in the study group were asked to describe their best and worst experiences during their undergraduate education. The answers given are shown in Table $3 \mathrm{a}$ and Table $3 \mathrm{~b}$. 
Table 3a. The Best Experiences Regarding History Education in Undergraduate Education

\begin{tabular}{lc}
\hline Codes & $\mathrm{f}$ \\
\hline Close communication with instructors & 16 \\
Getting to know my field & 13 \\
Internship & 7 \\
Social events & 5 \\
To be able to teach & 4 \\
Investigating my hometown during subject on the National Struggle & 3 \\
Attending the student congress & 1 \\
\hline
\end{tabular}

Table 3b. The Worst Experiences Regarding History Education in Undergraduate Education

\begin{tabular}{lc}
\hline Codes & $\mathrm{f}$ \\
\hline Future anxiety & 15 \\
My dilemmas about my profession & 9 \\
That my field is underrated & 8 \\
Too many theoretical courses & 5 \\
Pandemic period & 3 \\
None & 9 \\
\hline
\end{tabular}

When Table 3a is analyzed, it is noted that the best experience of teacher candidates in their undergraduate education is establishing communication with the instructors of the field and being able to comprehend their own fields. Upon these answers, it is possible to indicate that undergraduate education of teacher candidates was efficient. When Table $3 \mathrm{~b}$ is analyzed, it is noted that the worst experience of teacher candidates in their undergraduate education is future anxiety, employment and working conditions. It has been determined that teacher candidates do not have any bad experiences with undergraduate their education, there are only teacher candidates who find theoretical courses too much, and who fail to realize their dreams about the graduation due to pandemic process. Here are some answers from teacher candidates:

5HTC: My best experience was to carry out research about my hometown when learning about National Struggle. My worst experience was not being able to hold our graduation ceremony during the pandemic period.

As the best experience, I can count the activities, excursions, social and cultural activities I participated outside of my university education. I do not have a very bad experience that negatively affected me.

11HTC: I do not have any bad experience. We went to other schools to do research for the educational sciences course. The interview I had with the students and teachers there was the best experience of my education life.

19HTC: I can say that the best experience is to internalize my field by reading books and repeating courses. I can say that my worst experience is that I was caught in a dilemma about whether I wanted to become a teacher or an academician.

33HTC: My worst experience is that History teaching does not find the value it deserves in today's conditions. In making this comment, I regret to say that the problem is not in the History departments, but because History is not given importance overall. My best experience is that, after all, my students called me teacher during the internship.

3.4 Findings Regarding the Opinions of History Teacher Candidates about the Content of the Courses They Took in Their Undergraduate Education

When Table 4 is analyzed, it can be stated that history teacher candidates have more negative opinions about course contents. It can be discussed that the negative thoughts of the teacher candidates are mainly collected in the way that theoretical aspect of them is more, while practical content is less. Positive evaluations of the course contents were expressed as the undergraduate program providing a general view and equipment related to the field. Here are the answers from some teacher candidates:

12HTC: I am quite pleased. But I find it absurd that we take Ottoman Turkish course. After all, high school students do not have Ottoman Turkish lesson. I think the program should be prepared for us according to the lessons took by the audience we are going to address.

27HTC: The order of some courses we take may be changed. And courses that will bring a new perspective to the 
history can be added.

32HTC: Our courses are very detailed; this is actually designed for us to master the field. But I think there are few practical courses. Even if we know very well, it is necessary when teaching.

40HTC: There is a lot of theoretical information, yet few practical courses.

Table 4. The Opinions of History Teacher Candidates about the Content of the Courses They Took in Their Undergraduate Education

\begin{tabular}{llc}
\hline & \multicolumn{1}{c}{ Codes } & $\mathrm{f}$ \\
\hline \multirow{3}{*}{ POSITIVE } & Provides a general view of the field & 13 \\
& Provides equipment & 8 \\
& Provides satisfactory information & 6 \\
& Very detailed & 6 \\
& All very fine & 4 \\
& Too many theoretical courses & 20 \\
& Only few practical courses & 16 \\
& There are unnecessary courses & 7 \\
& Ottoman Turkish course is unnecessary & 5 \\
& The order in which lessons are taught should change & 3 \\
& Field and education should be combined & 3 \\
& Innovative history teaching aspect is lacking & 2 \\
& Intensity of the courses constitutes impediment for socialization & 1 \\
\hline
\end{tabular}

3.5 Findings Regarding the Opinions of History Teacher Candidates about the Courses They Deem Necessary and Unnecessary in Undergraduate Programs

Table 5. The Opinions of History Teacher Candidates about the Courses They Deem Necessary and Unnecessary in Undergraduate Programs

\begin{tabular}{|c|c|c|}
\hline & Codes & $\mathrm{f}$ \\
\hline \multirow{5}{*}{ Necessary } & Teaching practice & 34 \\
\hline & Private Education & 13 \\
\hline & Material & 11 \\
\hline & All field courses & 8 \\
\hline & Courses including Seljuk, Ottoman and Republican periods & 5 \\
\hline \multirow{7}{*}{ Unnecessary } & All necessary & 2 \\
\hline & Compulsory elective courses & 9 \\
\hline & Ottoman Turkish & 6 \\
\hline & Literature courses & 4 \\
\hline & Introduction to university life & 3 \\
\hline & Entrepreneurial culture & 3 \\
\hline & No unnecessary course & 1 \\
\hline
\end{tabular}

When Table 5 is analyzed, the first course that teacher candidates deem necessary in the undergraduate program is teaching practice. It was observed that teacher candidates primarily deem practical courses more necessary, while elective but compulsory courses and courses such as Ottoman Turkish and literature unnecessary. Here are some answers from the teacher candidates:

7HTC: Ottoman Turkish is an unnecessary course if a person is not thinking of getting a master's degree, where will $\mathrm{s} /$ he use it in her/his life? Since there is language requirement while getting master's degree, Ottoman Turkish condition should be required there, then it should be learned. I can say that teaching practice is the most necessary lesson of this program.

15HTC: There is no course that I consider unnecessary. I believe every course I take has contributed to me. However, I think that the instructors of some courses should teach them more effectively. 
36HTC: Entrepreneurial culture, introduction to university life. They did not contribute me anything, so I find it unnecessary.

39HTC: I consider the courses involving the Seljuk Ottoman Republic periods necessary. But we also had courses that we deemed unnecessary. For example, the introduction to university life

43HTC: Seljuk, Ottoman and the History of Republic of Turkey courses are indeed basic courses. However, I would like also to say that I find Ancient Age course we took in the first grade unnecessary.

\subsection{Findings Regarding the Evaluation of Practical Courses in Undergraduate Programs}

Table 5 includes the answers given by history teacher candidates in the study group when asked about their evaluations of practical courses in their undergraduate programs.

Table 6. Evaluation of Practical Courses in Undergraduate Programs

\begin{tabular}{lc}
\hline Codes & $\mathrm{f}$ \\
\hline Teaching practice is useful & 41 \\
They are not enough in numbers & 23 \\
Their contents are not suitable for the field & 11 \\
There are no practical courses suitable for the field & 5 \\
Inadequate teaching & 3 \\
They are enough in numbers & 3 \\
Their content is adequate & 1 \\
\hline
\end{tabular}

When Table 6 is analyzed, it can be argued that similar to previous finding, history teacher candidates regard the teaching practice as the most useful class for practical courses in the undergraduate program, and they find the number of practical courses insufficient, and fancy that the existing practical courses should be adapted to history education. Here are some answers from teacher candidates:

16HTC: Not only are the practical courses few, but the content was not designed for history teachers. For example, courses except drama and internship, community service are thought through reading and telling slides rather than application.

29HTC: I do not think the number of practical courses is sufficient. The application area of the courses offered theoretically to the student is quite scarce. I would say that the only practical course I have benefited from is the teaching practice.

34HTC: I cannot say that a practical course suitable for the field has been given so far. I mean, how are we going to explain the Ottoman Empire? Like this way, we need to see how the application will be on a special subject. Moreover, practical courses are few, yet exams are quite exhausting. They are not learning, but memorization oriented.

3.7 Findings Regarding the Evaluation of the Contribution of Undergraduate Education to the Personal and Professional Development

Table 7 and Table 8 include the answers of the teacher candidates when asked about the contribution of their undergraduate education to their personal and professional development.

Table 7. The Evaluations of the Contribution of Undergraduate Education to Personal Development

\begin{tabular}{lc}
\hline Codes & $\mathrm{f}$ \\
\hline Self-confidence & 22 \\
Doing research & 15 \\
Reading habit & 13 \\
I have matured & 7 \\
Communication skill & 5 \\
Empathy skill & 3 \\
I saw the resources for the field. & 2 \\
It has broadened my perspective. & 2 \\
Willingness to work & 2 \\
\hline
\end{tabular}


When Table 7 is analyzed, self-confidence, researching and reading habits take the first place in the statements of history teacher candidates on the contribution of their undergraduate education to their personal development. Here are the answers from some of the teacher candidates:

4HTC: The great contribution of the undergraduate program for me is that it teaches how to conduct scientific studies and it has a great contribution to the development of research-analysis skills.

13HTC: I have gained confidence in how to learn and teach any information. I can also say that my communication skills have improved.

24HTC: And in other field courses, I observed the resources that I can consult as reference work on a subject by having knowledge of much information, many resources, articles and works. Thanks to this, I have gained a reading habit.

37HTC: Since we take courses in more than one field, one's the point of view of the goes beyond monotony. I suddenly started to look at an event from different angles, to investigate the causes of the events better.

Table 8. The Evaluations of the Contribution of Undergraduate Education to Professional Development

\begin{tabular}{lc}
\hline Codes & $\mathrm{f}$ \\
\hline I loved my profession & 31 \\
Communicating with the student & 18 \\
My knowledge has increased & 11 \\
I looked up to my instructors & 7 \\
I have developed teaching skills & 5 \\
I learned to use historical knowledge & 3 \\
\hline
\end{tabular}

When Table 8 is analyzed, it can be implied that in their statements about the contribution of their undergraduate education to their professional development, history teacher candidates expressed that their interest in their profession and their communication with students increased. Here are some answers of the teacher candidates:

9HTC: While I could not previously use and interpret historical information in my daily life, now I can really see the contributions of the past to the future, to the present.

17HTC: Our undergraduate program has a great professional contribution. Because from the first years, there is a system oriented to give presentations in the courses. But the real experience is the teaching skill we gained as a result of the internship practice we started in the senior year.

25HTC: We've learned that there are unknown aspects to every event in history. When we get to practice our profession in the future, we will teach them such knowledge in order to raise conscious generations.

44HTC: First of all, my knowledge has increased. And this made me love my profession, and I saw that this profession was just for me.

\section{Conclusion and Discussion}

To evaluate the results of this study aiming to get the thoughts of history teacher candidates who have recently graduated from the history teaching undergraduate program, it can be implied that for the history program, history teacher candidates in the study group generally have positive thoughts about the undergraduate education they received, they just found the course contents very theoretical and indicate that the number of applied courses should be increased. To examine in detail as sub-problems, it is possible to assert the following:

First of all, it can be said that the general evaluations of the teacher candidates in the study group pertaining to undergraduate education they received are positive. The teacher candidates evaluated the education they received as a qualified one, and as for the negative features, they stated that there are few educational sciences courses while too many courses with theoretical content exist. In similar vein, Kaya, Aslan and Günay (2013) revealed that teacher candidates generally think positively about their departments in their study with history teacher candidates.

According to the results of the research, it has been found out that the teacher candidates also expressed their dream history teacher as good historian who has abandoned the traditional patterns in history teaching, a teacher who can keep the interest of students alive, and has a command of educational sciences as well as field knowledge. When the answers of the teacher candidates are analyzed, it can be claimed that they depict a teacher who is conforming with 
innovative history teaching, who endears history, who tells the history enthusiastically, and who is open to innovations. In similar way, Kaya, Aslan and Günay (2013) acknowledged that the expectations of history teacher candidates after getting to department are to improve themselves in the field of history and to become a good history teacher. And in her study on the qualifications of a good history teacher, Çulha Özbaş (2014) emphasized the reflective history teachers who are active in the learning-teaching process, and can implement innovations in her/his class.

In addition to the finding above, it can be argued that the teacher candidates generally consider the undergraduate education they receive as sufficient to reach the history teacher of their dreams. Candidates who did not find it adequate stated that they found undergraduate education still useful in terms of guidance. In the study conducted with social studies teacher candidates, Akhan (2015) determined that they deemed the education they received at the university inadequate for their professional competence, and expected more from the courses and the instructors.

And according to the results of the research, it is recognized that the best experience of teacher candidates in their undergraduate education is the communication established with the instructors of the field and to comprehend their fields, while the worst experience is future anxiety, employment and working conditions. Similarly, in a study conducted by Erkan (2009) with history teacher candidates at various universities, it was revealed that teacher candidates were quite hopeless about finding a job.

As for the undergraduate program, it can be asserted that teacher candidates do not have any bad experiences, there are only teacher candidates who find theoretical courses too much, and who fail to realize their dreams about the graduation due to pandemic process. And in their study conducted with teacher candidates, Akhan and Kaymak (2020) also revealed that teacher candidates at the stage of graduation experienced graduation stress due to pandemic process.

According to the results of the research, it can also be argued that history teacher candidates have more negative opinions about course contents. It can be discussed that the negative thoughts of the teacher candidates on the course contents are gathered in the direction of the fact that theoretical aspect are more and practical content was less. Positive evaluations of the course contents were expressed as the undergraduate program providing a general view and equipment related to the field. Similarly, Akhan (2015) revealed that teacher candidates expressed the fact that theoretical courses on the Social Studies program were too many, and the practical courses were insufficient and inadequate as a deficiency.

According to the research results, it was determined that the first of the courses deemed necessary by the teacher candidates in the undergraduate program is the teaching practice course, and teacher candidates primarily deem practical courses more necessary, while elective but compulsory courses and courses such as Ottoman Turkish and literature unnecessary. Şahin, Kartal and İmamoğlu (2013) similarly presented that Preschool Education teacher candidates found the application dimension of their program lacking and the theoretical content too much, and they were compulsorily select among elective courses which were determined by the respective department. Şahin and Kartal (2013) also indicated that the teacher candidates who evaluated the classroom teaching program found the practice-oriented courses inadequate.

Also in this research it can be argued that similar to previous finding, history teacher candidates regard the teaching practice as the most useful one for the practical courses in the undergraduate program, they find the number of practical courses insufficient, and the existing practical courses should be adapted to history education. Again Akhan (2015) discussed that teacher candidates point out that teaching practice and practical courses as ones that contribute to their professional development the most among courses in their program, and that they wished to increase total number of such courses. In his study, Alaca (2019) argued that history teacher candidates emphasized the importance of the history learning by engaging, experiencing and observing it more, but the fact that teacher candidates did not have the grasp of the effect of the methods and techniques in history teaching can be explained by the lack of adequately observing practical examples.

Finally, it can be implied that while "self-confidence, researching and reading habits" took the first place in the statements of the history teacher candidates on the contribution of their undergraduate education to their personal development, in their statements about their contribution to their professional development they expressed that "their interest in their profession and their communication with students increased". And in her study on the professional skills of history teacher, Karabağ (2014) revealed that shaping the professional knowledge and skills of history teachers correctly would improve the quality of history lesson.

To summarize the results of this research that includes the evaluations of the history teacher candidates on their own 
undergraduate education, and that it was also attempted to explain along with the examples in the literature, it is possible to state that the teacher candidates in the study group appreciated their undergraduate programs apart from theoretical structures, that they had access to sufficient equipment during their field-oriented undergraduate education, and that they made use of their education in terms of their professional and personal development. As for the scarcity of practical courses that the teacher candidates in the study group considered lacking for their undergraduate education, and that the contents were not formed according to their field, in the light of this study, it is possible to suggest that the number of practical courses the teacher candidates need for the history undergraduate programs may be increased, and that their contents may be reorganized.

\section{References}

Akhan, N. E. (2015). Views of social studies teacher candidates on social studies undergraduate program. The Journal of Academic Social Science Studies, 32(III), 267-289.

Akhan, N. E., \& Kaymak, B. (2020). A common anxiety in the final stage of graduation: the reality of pandemic. Akademik Sosyal Araştırmalar Dergisi, 8(110), 95-108.

Aktekin, S. (2009). Lise öğrencilerinin tarih derslerinde yerel tarih konularının öğretilmesiyle ilgili görüşleri. Milli Ĕgitim, 182, 331-352.

Alabaş, R. (2016). Türk eğitim tarihi dersinin önemi hakkında öğretmen adaylarının görüşleri. Cumhuriyet International Journal of Education, 5(4), 89-102. https://doi.org/10.30703/cije.321417

Alaca, E. (2019). Tarih öğretmeni adaylarına göre "tarih öğretimi ve tarih öğretmeni nasıl olmalıdır? In Nuri Yavuz'a Armağan, N. Hayta, B. Demirtaş ve M. Can (Ed.), "Tarihin İzinde Bir Ömür” içinde (s.10-20), Ankara, Berikan Yayınevi.

Angvik, M. (2001). The teaching of controversial history for the global society. K. Pellens together with G. In Behre, E. Erdmann, F. Meier and S. Popp Reid (Eds.), the Historical Consciousness and History Teaching in a Globalizing Society (pp. 35-58). Germany: Peter Lang.

Ata, B. (2001). Müzelerle ve tarihi mekânlarla tarih öğretimi: Tarih ögretmenlerinin müze eğitimine ilişkin görüşleri (Unpublished doctoral thesis). Gazi Üniversitesi, Sosyal Bilimler Enstitüsü, Ankara.

Avcı Akçalı, A. (2015). Kurum ve uygulamada sınıf dışı tarih öğretimi algısı: Öğretmen ve aday öğretmen görüşleri. Eğitim ve Bilim, 40(181), 117-137.

Bal, M. S. (2011). Türkiye'de tarih öğretiminin sorunları ve çözüm yolları konusunda öğretmen adayı ve öğretmen görüşlerinin karşılaş̧ırılması. Mustafa Kemal Üniversitesi Sosyal Bilimler Enstitüsü Dergisi, 8(15), 371-387.

Boadu, G., Awuah, M., Ababio, A. M., \& Eduaquah, S. (2014). An examination of the use of technology in the teaching of history: A study of selected senior high schools in the Cape Coast metropolis, Ghana. International Journal of Learning, Teaching and Educational Research, 8(1), 187-214.

Büyüköztürk, Ş., Çakmak, E. K., Akgün, Ö. E., Karadeniz, Ş., \& Demirel, F. (2010). Bilimsel araştırma yöntemleri. Ankara: Pegem A Yayıncılık.

Conderman, G., \& Walker, D. A. (2015). Assessing dispositions in teacher preparation programs: Are candidates and faculty seeing the same thing? The Teacher Educator, 50(3), 215-231. https://doi.org/10.1080/08878730.2015.1010053

Crabtree, D. (2001). Retrieved from The Importance of history. Retrieved 15.02.2021 from https://gutenberg.edu/2001/02/the-importance-of-history/

Cresswell, J. W. (2018). Nitel araştırma yöntemleri: Beş yaklaşıma göre nitel araştırma ve araştırma deseni (Qualitative Inquiry and Research Design: Choosing among Five Approaches) (4th Ed.). (Trans. Edt.: Mesut Bütün ve Selçuk Beşir Demir). Ankara: Siyasal.

Creswell, J. W. (2007). Qualitative inquiry \& research design: Choosing among five approaches. USA: SAGE Publications.

Çulha Özbaş, B. (2014). İyi bir tarih öğretmeninin nitelikleri (öğretmen tipolojisi). In M. Safran (Ed.), Tarih Nasıl Öğretilir? Tarih Öğretmenleri İ̧cin Özel Öğretim Yöntemleri. İstanbul: Yeni İnsan, s. 367-372.

Culpin, C. (2007). What kind of history should school history be? The Historian, Autumn. The Medlicott Medal Lecture. 
Demircioğlu, İ. H. (2008). History teachers' attitudes towards museum visits: A Turkish perspective. Teaching History Journal, September, 24-30.

Epik, C. (2004). The effects of museums on high school students success in their history lessons and their abilities of remembering the subjects (Unpublished Master's Degree Thesis). Dokuz Eylül Üniversitesi, Eğitim Bilimleri Enstitüsü, İzmir.

Erkan, S. (2009). Türk üniversitelerinde tarih ögrenimi (Unpublished doctoral dissertation). Ankara: Gazi Üniversitesi Eğitim Bilimleri Enstitüsü.

Fausser, K. (2000). Dimensions of a complex concep. In Sharon Macdonald (Ed.), Approaches to European Historical Consciousness: reflections and provocations, 41-51. Hamburg: Edition Korber-Stiftung.

Fielding, J. (2005). Engaging students in learning history. Canadian Social Studies, 39(2), 1-8.

İlhan, A. Ç. (2005). 21. yüzyılda öğretmen yeterlikleri. Bilim ve Aklın Aydınlı̆̆ında Ĕ̈itim Dergisi, 58, 55-58.

Karabağ, Ş. G. (2014). Tarih öğretmeninin mesleki becerilerini şekillendiren unsurlar. In M. Safran (Ed.), Tarih Nasıl Ögrretilir? In Tarih Öğretmenleri İçin Özel Ögretim Yöntemleri (pp. 373-376). İstanbul: Yeni İnsan.

Kaya, R., Aslan, H., \& Günal, H. (2013). The Views of Prospective Teachers about Reasons of Department Choices and Their Expectations from the Department (The Example of Ataturk University. Turkish History Education Journal, 2(2), 1-31.

Kazmer, M. M., \& Xie, B. (2008). Qualitative interviewing in internet studies playing with the media, playing with the method. Information, Communication \& Society, 11(2), 257-278. https://doi.org/10.1080/13691180801946333

Kent, S. I. (2000). Problems of beginning teachers: Comparing graduates of bachelor's and master's level teacher preparation programs. The Teacher Educator, 35(4), 83-96. https://doi.org/10.1080/08878730009555239

Kyvig, D. E., \& Marty, M. A. (2000). Yanı başımızdaki tarih. N. Özsoy (Trans.). İstanbul: Türkiye Ekonomik ve Toplumsal Tarih Vakfi.

Lee, P. (1984). Historical Imagination. In Dickinson, P. J. Lee \& P. J. Rogers (Eds.), Learning History. London: Heinemann Educational Books, 85-116.

Lorentzen. S. (2000). Key Aspects of European Historical Consciousness. In S. Macdonald (Ed.), Approaches to European Historical Consciousness: reflections and provocations, 32-40. Hamburg: Edition Korber-Stiftung.

McDiarmid, G. V., \& Vinten Johansen, P. (2000). A catwalk across the great divide redesigning the history teaching methods course. (Ed. Peter N. Stearns, Peter Seixas and Sam Wineburg) withinside Knowing, Teaching, and Learning History National and International Perspectives, 156-177. New York and London: New York University Press.

MEB (2017). Öğretmenlik mesleği genel yeterlikleri. Öğretmen yetiştirme ve geliştirme genel müdürlüğü. Ankara.

Meho, I. L. (2006). E-mail interviewing in qualitative research: a methodological discussion. Journal of the American Society for Information Science and Technology, 57(10), 1284-1295. https://doi.org/10.1002/asi.20416

Merriam, S. B. (2018). Nitel araştırma. desen ve uygulama için bir rehber (3rd ed.). (Trans. Edt. Selahattin Turan). Ankara: Nobel.

Miles, M. B., \& Huberman, A. M. (1994). Qualitative data analysis: an expanded source book (2nd ed.). Thousand Oaks, CA: Sage.

Milli Eğitim Bakanlığı (2018). Retrieved from Özel alan yeterliklerinin yürürlükten kaldırılması. Retrieved 18.02.2021 from https://oygm.meb.gov.tr/www/ozel-alan-yeterliklerinin-yururluktenkaldirilmasi/icerik/647

Nair, S. M., \& Narayanasamy, M. (2017). The effects of utilising the concept maps in teaching history. International Journal of Instruction, 10(3), 109-126. https://doi.org/10.12973/iji.2017.1038a

Nygren, T. (2011). Veteran teachers' strategies in history teaching history didactic narratives from practice in Sweden. The Processes of History Teaching, 90-104. Publisher: Karlstad University PressEditors: Per Eliasson, Kenneth Nordgren, Carina Rönnqvist.

Ogunniyi, O. J. (2012). History and Its teaching. IPEDR, 48(3), 11-13.

Pamuk, A. (2017). Tarih öğretimi ve kimlik çalışmaları. In İsmail Hakkı Demircioğlu and Ebru Demircioğlu. (Eds.), 
Türkiye'de Tarih Eğitimi Araştırmaları (pp. 259-270). Ankara: Pegem Akademi. https://doi.org/10.14527/9786053188322.09

Şahin, Ç., \& Kartal, O. Y. (2013). Sınıf Öğretmeni Adaylarının Sınıf Öğretmeni Yetiştirme Programı Hakkındaki Görüşleri. Uşak Üniversitesi Sosyal Bilimler Dergisi, 6(1), 164-190. https://doi.org/10.12780/UUSBD143

Şahin, Ç., Kartal, O. Y., \& İmamoğlu, A. (2013). Okul Öncesi Öğretmen Yetiştirme Programı Hakkında Okul Öncesi Öğretmen Adaylarının Görüşleri. Ahi Evran Üniversitesi Kırşehir Eğitim Fakültesi Dergisi (KEFAD), 14(1), 101-118.

Schanely, S. D. (2006). Towards an understanding of an outdoor education program: Listening to participants' stories (Unpublished doctoral dissertation). University of Florida, Florida.

Shulman, L. S. (1986). Those who understand: knowledge growth in teaching. Educational Researcher, 15(2), 4-14. https://doi.org/10.3102/0013189X015002004

Stanovich, P. J., \& Jordan, A. (2002). Preparing general educators to teach in inclusive classrooms: Some food for thought. The teacher educator, 37(3), 173-185. https://doi.org/10.1080/08878730209555292

Stearns, P. N. (2009). Why study history? Erkan Dinç (Trans.). Uşak Üniversitesi Sosyal Bilimler Dergisi, 2(1), 118-127.

Steeves, K. A. (1998). Working together to strengthen history teaching in secondary schools. Retrieved 17.02.2021 from https://files.eric.ed.gov/fulltext/ED426939.pdf

Taylor, T., \& Young, C. (2003). Making history: A Guide for the teaching and learning of history in Australian schools. Canberra: Commonwealth of Australia.

Torp, R. (2014). Historical Consciousness, Historical Media, and History Education. UMA Universitet, Högskolan Dalarna.

Tosuntaş, Ş. B. (2020). Öğretmenlik mesleği genel yeterliklerinin incelenmesi. Academy Journal of Educational Sciences, 4(1), 53-61. https://doi.org/10.31805/acjes.746234

Turan, R. (2019). Ĕgitim fakültelerinin tarih öğretmenliği lisans programı ders çizelgesinde 2018 yllında gerçekleştirilen değişiklik üzerine bir değerlendirme. 1 Mayıs Sosyal Politikalar ve Bilimsel Araştırmalar Kongresi,1 Mayıs 2019, Ankara, Türkiye.

Watts, R. (1993). Implementing the national curriculum: term 1. Teaching History, 70, 13-17.

White, J. (1992). The purpose of school history: has the national curriculum got it right? In P. Lee, D. Shemilt, J. White, J. Slater \& P. Walsh (Ed.), the The Aims of School History (pp. 9-19). Institute of Education, London File series. London: Tufnell Press.

Wineburg, S. (2000). Making Historical Sense. In Peter, N. S., Peter, S. and Wineburg, S. (Eds.), the Knowing, Teachig and Learning History: National and International Perspectives (pp. 306-326). New York.

Yıldırım, A., \& Şimşek, H. (2013). Sosyal bilimlerde nitel araştırma yöntemleri (9rd ed.). Ankara: Seçkin.

Yin, R. (1984). Case study research: design and methods (3rd ed.). California: Sage Publications.

Yök. (2018). Tarih öğretmenliği lisans programı. Ankara.

\section{Copyrights}

Copyright for this article is retained by the author(s), with first publication rights granted to the journal.

This is an open-access article distributed under the terms and conditions of the Creative Commons Attribution license (http://creativecommons.org/licenses/by/4.0/). 